\title{
PEMBERIAN MEJA POTONG KAIN ERGONOMIS UNTUK MENINGKATKAN PRODUKSI KERJA USAHA JAHIT
}

\author{
Rahmi M Sari, Khalida Syahputri, Farida Ariani \\ rahmi.m.sari@gmail.com
}

\begin{abstract}
ABSTRAK
Usaha Jahit yang berada di Kota Medan sangat berkembang dengan pesat. Hal ini disebabkan oleh tingginya minat masyarakat untuk menjahitkan bahan dasar pakaian sehingga akhirnya didapat sebuah desain yang sesuai dengan keinginan pelanggan. Demi mendapatkan ukuran dan desain yang susai tersebut, maka tiap usaha jahit harus menggunting kain sesuai dengan pola yang telah ditetapkan. Dalam proses kerja penjahitan, pemotongan pola merupakan bagian yang paling menentukan tingkat kesesuaian antara model pakaian dan hasil akhir berupa produk pakaian. Berdasarkan hasil observasi awal dengan mitra, mereka sering kesulitan pada saat proses pemotongan kain tersebut dikarenakan sempit dan terbatasnya ukuran meja potong kain. Dampak dari terbatasnya meja potong adalah pola kain yang digunting menjadi tidak sesuai dengan ukuran yang telah ditetapkan. Target yang telah tercapai adalah tersedianya meja potong ergonomis yang sesuai dengan dimensi dan ukuran tubuh pekerja sehingga dapat mendukung proses kerja jahit dan nantinya dapat mkeningkatkan kualitas produksi usaha jahit.
\end{abstract}

\section{Kata Kunci : Usaha Jahit, Meja Potong Kain, Ergonomis}

\section{PENDAHULUAN}

Salah satu jenis usaha mikro antara lain usaha jahit. Usaha jahit merupakan suatu industri yang menghasilkan pakaian yang menjadi salah satu kebutuhan manusia paling mendasar selain pangan dan papan. Seiring dengan semakin majunya peradaban manusia yang memfungsikan pakaian bukan sekedar sebagai penutup badan atau aurat namun juga sebagai sarana menghias diri sehingga orang tidak akan puas memiliki satu dua pakaian namun juga banyak pakaian yang bagus meski pakaian lama masih layak pakai. Kebutuhan ini dibutuhkan oleh setiap orang tetapi hanya sedikit orang yang memiliki kemampuan dalam menekuni bidang tata busana tetapi tidak semua orang mau menekuni bidang ini karena harus memiliki ketelitian yang cukup besar dalam menjalankan usahanya.

Dalam menjalankan usaha usaha jahit, ada beberapa hal penting yang harus diperhatikan untuk meraih kesuksesan diantaranya adalah tepat waktu, tidak serakah dan berinovasi. Seorang penjahit harus pintar- pintar dalam mengatur waktu agar semua pesanan dapat terpenuhi minimal sesuai permintaan pelanggan dan lebih baik jika selesai kurang dari waktu permintaan karena hal tersebut akan membuat pelanggan percaya. Selain itu, seorang penjahit harus mengetahui kemampuan yang dimilikinya dan jangan terlalu memaksakan diri. Hal yang dikhawatirkan adalah apabila terlalu banyak pesanan dan tidak sesuai dengan kemampuan, maka dapat menyebabkan keterlambatan yang mengakibatkan kekecewaan pelanggan.

\section{PERMASALAHAN MITRA}

Permasalahan yang timbul dalam kegiatan pengabdian masyarakat pada saat pemotongan kain adalah tidak adanya tempat yang memadai untuk melakukan pemotongan kain. Pekerja biasanya hanya menggunakan meja sederhana untuk memotong kain. Selain meja, pekerja juga menggunakan lantai untuk memotong kain. Hal ini sangat tidak efektif untuk melakukan pekerjaan tersebut, banyak kendala yang dihadapi, misalnya kain yang digunakan berukuran besar, kain yang digunakan licin dan halus sehingga mudah untuk tergelincir diatas permukaan meja. Apabila kain yang digunakan berukuran besar, pekerja biasanya menggunakan lantai sebagai tempat untuk memotong kain. Dalam sekali kegiatan 
Rahmi M Sari. et al. Pemberian Meja Potong Kain Ergonomis Untuk Meningkatkan...

pemotongan, mitra I dapat membentuk pola untuk 10 potong kain sebagai proses awal dalam penjahitan. Jika posisi pemotongan dilakukan di lantai secara terus menerus, akan mengakibatkan resiko bagi pekerja karena postur tubuh pekerja pada saat melakukan pemotongan kain di lantai dilakukan dalam posisi kaki terlipat dan membungkuk. Posisi membungkuk dan kaki terlipat untuk waktu yang sangat lama beresiko terhadap keluhan otot pekerja, juga akan beresiko kain menjadi kotor jika diletakkan di lantai.

\section{TUJUAN KEGIATAN}

pengembangan teknologi pada bagian pemotongan kain. Suatu rancangan meja untuk pemotongan kain bisa dilakukan untuk mengatasi permasalahan di atas. Rancangan meja potong yang bisa dipanjangkan sehingga bisa disesuaikan untuk ukuran kain yang besar serta meja tersebut bisa dilipat sehingga memudahkan untuk melakukan penyimpanan. Selain itu dengan adanya meja potong kain dapat menghindarkan kain menjadi kotor dan jorok selama proses pemotongan sebagai akibat posisi kain yang berada di lantai.

\section{TARGET DAN LUARAN}

\subsection{Target}

Adapun tujuan kegiatan dari Pengadian masyarakat ini adalah Pengembangan teknologi pada bagian pemotongan kain di usaha jahit dalam rangka meningkatkan produktivitas UKM.

\subsection{Luaran}

Adapun luaran atau output dari kegiatan pengabdian ini adalah:

1. Rancangan meja pemotong kain yang bisa dipanjangkan dan disesuaikan dengan ukuran kain sehingga memudahkan pekerja dalam memotong kain.
2. Perbaikan metode kerja dengan adanya fasilitas meja pemotong kain yang baru diharapkan pekerja dapat bekerja secara ergonomis sehingga dapat meningkatkan produktivitas usaha jahit.

\section{METODE PELAKSANAAN}

Metode Pelaksaanaan Kegiatan yang dilakukan pada pengabdian pada masyarakat ini adalah;

1. Sosialisasi pemanfaatan perkakas bantu pada proses pemotongan kain dalam bentuk ceramah.

2. Rancang bangun meja potong kain ergonomis

3. Pengadaan meja potong kain ergonomis

4. Workshop pemakaian meja potong kain ergonomis

5. Pendampingan pemakaian meja potong kain ergonomis.

Pelaksanaan kegiatan yang dilakukan untuk memecahkan masalah adalah;

1. Pendampingan akan memberikan masukan dan bimbingan serta pelatihan tentang proses produksi serta rancang bangun meja potong kain ergonomis.

2. Rotasi materi dimana tim ahli akan memberikan perbandingan proses pemotongan kain dengan cara tradisional tanpa menggunakan meja maupun dengan menggunakan meja sederhana dengan pemakaian fasilitas rancangan sehingga kegiatan menjadi ergonomis

3. Transfer Ipteks melalui pelatihan penggunaan meja potong kain ergonomis untuk memudahkan pekerja dalam melaksanakan pekerjaannya

Kegiatan pengabdian pada masyarakat mengharapkan partisipasi kedua mitra berupa;

1. Kesediaan waktu dan tempat untuk pelaksanaan kegiatan penerapan program.

2. Kesediaan waktu untuk diwawancarai dan berdiskusi berkenaan masalah yang dihadapi.

3. Kontribusi dalam mengisi kuesioner SNQ untuk mengetahui keluhan musculoskeletal pada proses pemotongan 
Rahmi M Sari. et al. Pemberian Meja Potong Kain Ergonomis Untuk Meningkatkan...

dengan postur tubuh bungkuk dan kaki terlipat

4. Mitra akan mengisi kuesioner SNQ untuk mengetahui keluhan musculoskeletal setelah pemakaian meja potong kain ergonomis.

5. Kesediaan mitra pada pemakaian mejapotong kain ergonomis.

6. Kesediaan mitra untuk bekerja dengan metoda kerja baru yang ergonomis.

7. Kesediaan mengikuti sosialisasi, pelatihan dan workshop pemakaian meja potong kain ergonomis.

Kesediaan untuk bersama-sama dengan tim pelaksana pengabdian untuk menetapkan teknis pelaksanaan kegiatan dan strategi pendekatan dengan pekerja demi terlaksananya kegiatan pengabdian pada masyarakat.

\section{HASIL}

Pelaksanaan kegiatan yang dalam hal ini dilakukan oleh ketua pelaksana kegiatan pengabdian masyarakat berupa 1 (satu) unit meja potong kain ergonomis kepada pemilik UKM usaha Jahit. Pelaksana Kegiatan menjelaskan secara detail tentang instruksi pemakaian meja potong kain tersebut mulai dari proses awal bagaimana meletakkan kain diatas meja potong, lalu menahannya untuk mencegah kain yang akan dipotong berubah posisi sehingga mengakibatkan terjadinya kesalahan dalam pemotongan yang tentu saja dapat berakibat fatal.



Gambar 1. Penggunaan Meja Potong Kain Ergonomis

\section{KESIMPULAN DAN SARAN}

Meja Potong kain ergonomis menyebabkan kegiatan pemotongan kain sesuai pola yang selama ini membutuhkan waktu yang cukup lama mencapai 1 jam dan tenaga yang cukup besar dapat dikurangi cukup selama 10 menit saja dengan 1 orang pekerja. Hal tersebut sangat memudahkan dan mempercepat proses pemotongan kain sesuai pola. Pemotongan lebih cepat dan lebih mudah mengakibatkan waktu luang yang cukup banyak sehingga dapat dipergunakan untuk melakukan proses penjahitan pola menjadi pakaian sesuai pesanan.

\section{DAFTAR PUSTAKA}

1. Nielsen, M., Moritz Storring, Thomas B. Moeslund, Erick Granum, 2003, A Procedure for Developing Intuitive and Ergonomic Gesture Interface for ManMachine Interaction, Technical Report CVMT 03-01, Aalborg University, Denmark. 2. 2.

2. Nurmianto, Eko, 2004, Ergonomi, Konsep Dasar dan Aplikasinya, PT. Guna Widya, Jakarta.

3. Sumber Berita: www.pemkomedan.go.id

http://pemkomedan.go.id/new/halpengembangan-daya-saing-koperasi-usahamikro-kecil-danmenengah.html\#ixzz3oeQS8fw4 